Research Report No. 7/2009

\title{
A Preliminary Exploration of the Elements of Expert Performance in Legal Writing
}

Shelley M. Kierstead

Osgoode Hall Law School of York University, skierstead@osgoode.yorku.ca

Erika Abner

Follow this and additional works at: http:/ / digitalcommons.osgoode.yorku.ca/clpe

\section{Recommended Citation}

Kierstead, Shelley M. and Abner, Erika, "A Preliminary Exploration of the Elements of Expert Performance in Legal Writing" (2009). Comparative Research in Law \& Political Economy. Research Paper No. 7/2009.

http://digitalcommons.osgoode.yorku.ca/clpe/122 


\section{Comparative Research in Law \& Political Economy}

CLPE RESEARCH PAPER 07/2009

Erika Abner and Shelley Kierstead

\section{A Preliminary Exploration of the Elements of Expert Performance in Legal Writing}

EDITORS: Peer Zumbansen (Osgoode Hall Law School, Toronto, Director, Comparative Research in Law and Political Economy, York University), John W. Cioffi (University of California at Riverside), Nassim Nasser (Osgoode Hall Law School, Toronto, Production Editor) 

CLPE Research Paper 07/2009

Vol. 05 No. 02 (2009)

\title{
Erika Abner and Shelley Kierstead
}

\section{A PRELIMINARY EXPLORATION OF THE ELEMENTS OF EXPERT PERFORMANCE IN LEGAL WRITING}

\begin{abstract}
This paper describes results of focus group research conducted with senior advocacy lawyers in relation to the lawyers' characterization of expert legal writing. The results suggest an important interplay between product and process, and are consistent with general theoretical models of expertise that characterize the writing process as exploratory, recursive, reflective and responsive. The results may also be linked with existing studies of school to work transitions. The authors also describe how the research results tie into a longer term research project aimed at developing a description of increasingly sophisticated writing competencies that can be expected of lawyers as they progress through their careers.
\end{abstract}

Keywords: "Legal writing", "Legal profession," "Legal education" and "Expertise."

JEL classification: K30, K39

\author{
Erika Abner, \\ Educational Consultant \\ Faculty of Medicine, Postgraduate Medical Education Office, University of Toronto. \\ Email: eabner@erikaabner.com \\ Shelley Kierstead, \\ Assistant Professor \\ Osgoode Hall Law School, York University. \\ Email: SKierstead@osgoode.yorku.ca.
}




\title{
A PRELIMINARY EXPLORATION OF THE ELEMENTS OF EXPERT PERFORMANCE IN LEGAL WRITING
}

\author{
Erika Abner and Shelley Kierstead
}

\section{INTRODUCTION}

This paper describes our exploratory and descriptive research into the elements of expert performance in legal writing. This research is intended to provide a framework for a more comprehensive research project designed to develop a description of increasingly sophisticated writing competencies that can be expected of lawyers as they progress through their careers. Before charting the process by which expert legal writing capacity is acquired, it seems necessary to develop some ideas about what expertise looks like, and how those who are considered experts characterize their journey to expertise. We also wanted to analyze how these findings meshed with existing academic theories of expertise.

There is virtually no debate about the importance of proficient written communication within the practice of law. The venerable MacCrate Report (1992) lists oral and written communication skills as fifth within the top ten fundamental skills, while the more recent Carnegie Report (Sullivan, Colby, Wegner, Bond, \& Shulman, 2007) notes the importance of teaching and learning legal writing in law school, asserting that legal writing holds the potential to bridge the three apprenticeships of head, heart and hands. In their seminal article chronicling the gaps between law firms and law schools, Garth and Martin (1993) note that partners within law firms expect young lawyers to enter firms with the ability to communicate effectively in both oral and written contexts, and with the ability to instill confidence in clients. For advocacy lawyers in Ontario, who form the majority of our research participants, the need for highly effective writing skills has arguably become a more pronounced practice component in light of increased judicial expectation that written materials will be filed prior to oral presentations in court. ${ }^{1}$

Despite the recognition of the importance of legal writing, practitioners and judges continue to bewail the poor writing skills of new graduates and excoriate law schools for ineffective teaching (Gallacher, 2007; Hyatt, 2007; Kosse \& ButleRitchie, 2003). Oddly, these

\footnotetext{
- Erika Abner is an Educational Consultant with the Faculty of Medicine, Postgraduate Medical Education Office, University of Toronto. Email: eabner@erikaabner.com; Shelley Kierstead is an Assistant Professor at Osgoode Hall Law School, York University. Email: SKierstead@osgoode.yorku.ca.

${ }^{1}$ The judicial expectation is derived from procedural rules which either mandate or allow for the submission of written materials in advance of oral hearings. See, for example, the Ontario Rules of Civil Procedure, R.R.O. 1990, Reg. 194, rules 20 (summary judgment); 21 (determination of issue before trial): 22 (special case); 37 (motions general); 42 (discharge of certificate of pending litigation); 61 (appeals); 68 (judicial review); 77 (settlement conference); and 78 (pre-trial conference).
} 
commentators do not consider the vast divide between learning in school and learning in practice; nor do they consider the time element in developing expertise.

We note at this point that we will pay scant attention to the extensive literature on legal reasoning, or teaching students to "think like a lawyer." While valuable, our research focuses on legal writing as learning to "solve problems like a professional", which is best captured in the following quotation:

Effective lawyers do not practice law. They solve problems, using law as one among many professional tools. "Thinking like a lawyer" is not the same thing as "solving problems like a professional." "Thinking like a lawyer" is a label used by doctrinal teachers for a collection of textual interpretation skills and heightened forms of skepticism. Although these are certainly useful in professional life, they are only part of the mental processes needed to solve professional problems......so much energy has been devoted to textual interpretation and skepticism that we actually know very little about how effective lawyers go about solving problems. (R. Neumann, Jr., 2000 at 405)

The work proceeds as follows. Part 1 summarizes the key expertise literature, including expertise in writing and the studies on novice-expert lawyers relied on for analytical purposes within this work. This Part also briefly reviews the research literature on the transition from school to work as new professionals learn to write in the workplace. Part 2 follows with a description of the recruitment and methodology used for the focus group research that forms the foundation for this paper. In Part 3, we discuss themes revealed through the focus groups, and in Part 4, we discuss how the findings relate to expertise theory, as well as how they will assist us to pursue the larger project that we envision. In the course of this discussion, we also make suggestions and raise questions about teaching and learning legal writing that may assist those who are engaged in the facilitation of legal skills development for law students and early-years practitioners. If, indeed, the acquisition of writing expertise is a "process" that requires both exposure to various kinds of legal problem solving opportunities and ongoing writing practice and feedback, the landscape for training law students and young lawyers could change significantly.

\section{PART 1: EXPERTISE LiterATURE}

\section{A. EXPERTISE - OVERVIEW}

Unlike expertise in the legal field, expert performance in many other disciplines has been studied quite extensively. We do not aim to present an exhaustive account of this work, but rather to highlight a number of ways that research suggests expert performance tends to be illustrated. First, experts are more likely to generate best solutions to problems such as chess moves (DeGroot, 1965); experts created best designs in a design task (Klein, 1993). Further, 
experts detect features of problems that novices do not see, such as patterns in X-Rays (Lesgold, 1988), and can perceive the "deep structure" of a problem or situation (Chi, Feltovich, \& Glaser, 1981). These competencies are related to what has been termed the ability to "name and frame" messy, ill-defined problems by first identifying the issue and then situating the problem within a larger picture in order to address it properly (Schön, 1983, 1987).

When solving problems, experts have the ability to call on relevant domain knowledge and strategies with minimal cognitive effort (Alexander, 2003), but they are also able to engage in more cognitively effortful processes when the automatic approach is insufficient (Bereiter \& Scardamalia, 1993). Experts are able to choose appropriate problem solving strategies, working forward from the given problem to the goal rather than working backwards (Larkin, 1980). Related to this characteristic is experts' ability to transition appropriately and effectively from heavy reliance on one set of resources to heavier reliance on another (Moulton, Regehr, Mylopoulos, \& MacRae, 2007), and the ability to know when to "slow down" in order to transition from automatic resources into greater reliance on effortful processes (Moulton et al., 2007). In many domains, it will take approximately ten years of intensive practice to acquire expertise (Ericsson, 1996).

While generally speaking, positive attributes are associated with experts, studies have also suggested certain negative characteristics of expertise (Ericsson, 2005). Most notably, experts sometimes inaccurately predict expert performance, with there being a direct correlation between level of expertise and inaccuracy of expectation. For example, the greater the level of expertise, the less likely one is to accurately predict how long it will take novices to complete a task (Hinds, 1999).

\section{B. NOVICE AND EXPERT LAWYERS}

The limited research base into the differences between novice and expert lawyers focuses on reading cases (Deegan, 1995; Lundeberg, 1987; Oates, 1997; Stratman, 2002) and initial client interviewing (Colon-Navarro, 1997; Sherr, 2000). One study (Weinstein, 1998) has examined the differences between novices (law students) and experts (specialist practitioners) in problem solving, in this instance an initial evaluation of a Social Security Disability claim. A review of the studies is contained in Appendix B.

The majority of the studies are exploratory and descriptive (Christensen, ; ColonNavarro, 1997) and compare the work of novices to more experienced lawyers or law professors or compare one group of students to another. The rhetoric researchers (Deegan, 1995; Lundeberg, 1987; Stratman, 2002) tend to utilize more mixed method research designs.

The line of research on reading cases, although limited, is the best developed. These studies tend to focus on learning expert strategies in order to develop teaching methods to assist first year law students in learning to read cases. In contrast, the interviewing studies (Colon- 
Navarro, 1997; Sherr, 2000) and the problem-solving study (Weinstein, 1998) address the value of different methods of legal education - traditional classroom, simulations, and clinical legal education - to experience.

All these studies used experience as a proxy for expertise, although in some studies the researcher examined the differences between experts within a specific field of law (e.g. immigration in Colon Navarro) to law students. None of the studies identified and used the "tenyear rule"; indeed, in some research practitioners with as few as 3 years of experience were deemed to be experts.

Despite the importance of oral and written communication in surveys and descriptions of lawyering competence (American Bar Association Section of Legal Education and Admissions to the Bar, 1992; American Law Institute-American Bar Association Committee on Continuing Professional Education, 1992) researchers have not turned their attention to legal writing (as distinguished from legal reading) and the stages of growth and development from novice to expert legal writers.

\section{WRITING THEORY}

Over the past thirty-odd years, the focus in relation to the development of good writing has shifted from the external written product to the internal processes associated with writing. When characterized in this way, writing becomes a "thinking" problem rather than an “arrangement" problem (L. Flower \& Hayes, 1977). Proper understanding of the writing process has been increasingly tied to an assessment of cognitive resources and demands. While there is still scant empirical literature about professional writing (Kellog, 2006), a number of commonalities appear to exist across writing fields. First, after assessing protocols of various expert writers, Flower and her colleagues concluded that there are three basic text production processes: planning (generating concepts and setting goals to be achieved within the text); translating ideas into text; and reviewing ideas and text (detecting faults at multiple levels) (Linda Flower, Hayes, Carey, Schriver, \& Stratman, 1986; L. Flower \& Hayes, 1977). By no means, however, are these stages linear - rather, the processes occur and reoccur throughout the planning, drafting, and re-drafting stages (Kellog, 1994). For example, revision, when practiced by expert writers within this context, is understood as a means to examine content, structure and voice (Fitzgerald, 1987).

It appears that there are specific attributes that expert writers bring to the writing task. One is the ability to solve the ill structured problems that often underlie the writing project (Bereiter \& Scardamalia, 1987). Another is the ability to avoid cognitive overload by relying on information that has been stored in long term memory to set goals and establish plans. The more experienced the writer, the greater is his or her repertory of semi-automatic plans and goals (Ericsson \& Kintsch, 1995). In turn, Stanovich and Cunningham's (1993) research indicates that 
extensive reading is a strong indicator of the amount of knowledge stored in long-term memory. This is interesting in light of recent research suggesting that overall amounts of reading have decreased for the general population and for incoming law students (Gallacher, 2007).

Domain specific knowledge is perhaps one of the key elements of the understanding of writing expertise. Expertise in one substantive area is not automatically transferable to another, and as such, an expert journalist will unlikely be able to generate an expert scientific report (Carter, 1996). Awareness of audience contributes to expert writing. Hyland (2001) documented the ways in which academic writers engaged their readership in 240 published articles across 10 disciplines. Finally, the general rule that it takes ten years of intensive practice to achieve excellence (Ericsson, 1996) applies to writing. For example, Wishbow (1988) drew this conclusion after examining the work of 66 poets while Gardner (1994) did so in relation to the works of T.S.Eliot.

\section{LEGAL WRITING AND ANALYSIS}

As referred to above, a small number of researchers have conducted empirical examinations of the behaviour of novice and expert lawyers in relation to reading, problem analysis and client interviewing. These studies have not examined differences in legal writing processes between novices and experts.

Some legal academics have used research from other fields to hypothesize about its implication for legal writing. Williams, for example, uses the domain specificity of expertise to explain, in part, the fact that law students tend to write poorly. With every transition, he posits, we become novices. Further, the cognitive load required to integrate the new substantive materials to which students are exposed leaves them with less cognitive energy to attend to basic skills such as grammar and sentence structure (Williams, 1991). Linda Berger has described the connections between prior research and the evolution of the "new rhetoric" in legal writing, which sees "writing as a process for constructing thought, not just the "skin" that covers thought (Berger, 1999). Rideout and Ramsfield (1994) also discuss the move away from traditional "formalist" legal writing.

There is extensive literature that sets out various criteria for sound legal reasoning and legal writing, but it is most often not linked to empirical research. Some reference is made to Garth and Martin's study of lawyers' competencies. For example, Wellford (2002) noted the study's conclusion that law firms are unsatisfied with sloppy editing, poor organization, significant grammatical and syntactical errors, poor logic, and faulty reasoning in writing samples provided by potential summer students. Neumann (2001) also refers to the Garth and Martin study. A small number report on research studies into judicial preferences (e.g. Lewis (2004) surveyed advocacy preferences of 80 federal and state appellate judges; see also (Bird \& Kinnaird, 2002) and (Garner, 2001-2002). Overall, however, the following categories of writing (with selected examples) emerge: Legal writing texts, generally prepared for first year law 
students with a focus on developing methods for presenting legal analysis (for example, IRAC Issue, Rule, Application, Conclusion), use of clear, concise language, recognition of audience, and differentiation between predictive and persuasive writing (Calleros, 2006; R. Neumann, 2005); General literature on writing in practice, emphasizing clarity and the avoidance of legalese (Armstrong \& Terrell, 2003; Garner, 2001; Goldstein \& Lieberman, 1989; Wydick, 1998); Classical rhetoric in legal writing, focusing on audience, tone, and purpose (Garner, 1991; Robbins, 2002-3; Smith, 2002); Judges writing with advice to lawyers, suggesting adherence to document length restrictions, use of point first writing, and avoidance of lengthy quotations (Laskin, 1999; Mackenzie, 2001); and Practitioner-based experience and advice on writing (Dickerson, 2005; Lee, 1996; Schiess, 2002; Stein, 2000).

\section{E. SCHOOL-WORK TRANSITION}

A discussion of the process of developing expertise as a legal writer should include the rich literature that has emerged in the past ten years on the transition from learning and writing in school to learning and writing at work. Understanding the differences in learning to write within these two worlds may lead us to explore different questions about the nature of expertise in legal writing.First, learning to write as a practitioner may include different stages than those required of other experts. Second, we may reach different conclusions and provide different recommendations on teaching and learning in school and the workplace, than we might reach for other forms of expert performance.

Several researchers have addressed the profound differences between writing at work and writing in school, described generally as differences in complexity, multifunctionality and implications of power relations (Dias, Freedman, Medway, \& Par, 1999, p. 151). These studies examined the transitions for engineers (Winsor, 2001), social workers (LeMaistre \& Paré, 2004; Paré \& LeMaistre, 2006; Winsor, 2001), architects (Dias et al., 1999), and government workers (Freedman \& Adam, 1996).

The following table, drawn from Dias, et al, provides an overview of these differences:

\section{School}

Social motives of writing: learning disciplinary language as well as to sort and rank students

Documents have spatial and temporal existence.

Texts have a discernible beginning and end.

Professors do not need students' written

\section{Work}

Social motive of writing is instrumental; primary aim is to get something done.

Documents have a continued physical existence as well as an ongoing role in institutional conversation and memory.

Texts are one strand in an intricate network of events, intentions, other texts, relationships and readers.

Written work is essential to the enterprise. 
work.

Objective of writing is clearly and Learning is a product of doing the work explicitly for learning

Planned curriculum

within the community of practice.

Improvisatory tasks; curriculum cannot be designed and sequenced (or possibly in a limited way).

Writing tasks, even within a simulation, are Writing tasks cannot be simplified. generally simplified. Roles of teacher and learner clearly defined.

Learners/novices must learn their multiple roles inside a network of complex relationships; need to learn new ways of learning.

Writing is shaped before the first draft. Completion of first draft is the start of a long process of iteration and shaping: "document cycling."

Individual ownership

Multiple owners, including the institution

Socially shared knowledge; teacher Distributed cognition; thinking in possesses knowledge, some of which she shares with students. partnership with others, including culturally provided tools and implements

The following description captures the differences in an architectural practice; these differences apply equally to law:

Students get little experience of collaboratively writing long documents of great complexity (often through collaboration with other parties outside the office, such as consultants based in different firms around the city), of writing that impacts on a situation in multifunctional ways, saying different things to different readers, or of writing that is implicated in power relations, either as the vehicle of the exercise of power or as the hostage to fortune that draws financial and legal retribution from others in power. Students do not give orders to others, go on record as making recommendations, sign certificates of payment for thousands of dollars, adjust their writing in the elight of the known backgrounds and foibles of a whole case of important other players, put documents meticulously away for indefinite storage, or get out of trouble by retrieving 5year-old documents from dusty files. They do not have to insert their writing into the middle of tangled intertextual webs and chains of speech, writing, and drawing, nor above all, do they see writing, fed into a situation, instigating massive financial flows and titanic physical operations with cranes, trucks, earthmovers, tons of materials and armies of differentiated workers. (Dias et al., 1999, at 181)

These considerations apply equally to the transitions that law students face as they move into practice (with the possible exception of the physical operations). In addition to the differences noted in the chart, writing in a law practice moves considerably faster than writing in school. A memo in law school may have a deadline of four-six weeks; the same memo in a law firm may be required within a day. Even experienced lawyers must sometimes act with unwelcome speed: 
"These days, responding to clients' and to opposing counsel's written communications is no longer a methodical and reflective process. Instead, it has become a series of quick reactions....." (West, 2004-5).

\section{PART 2: Methodology}

\section{A. ReCruitment AND Process}

This project used three focus groups of senior advocacy and research lawyers. Fifteen lawyers and one former Superior Court Justice participated in the focus groups. All participants had been in practice for at least 10 years and most had practiced over 20 years. Twelve were from large multi-service firms; four from small firms. Eleven were advocacy lawyers; four were research lawyers; and one was a former judge. Our objective in selecting this sample was to recruit a group of individuals with a significant amount of experience in legal writing and analysis who would generate a variety of ideas about the writing process. We also wished to obtain a sample size sufficient to unearth a sufficient number of themes within the focus group discussions to provide direction for future research initiatives.

Participants were recruited in three ways: 1) an invitation to all advocacy lawyers in three large multi-service law firms, where the invitation was sent by the firms' professional development director; 2) an invitation to the moot court "judges" for the first year moots at a large law school; and 3) an invitation to the research lawyers at four large multi-service law firms.

The focus group discussions were divided into two stages. In the first stage, participants were asked to reflect on the primary issues or problems they had noted in legal writing by students and new associates. Specifically, participants were asked to write down at least three problems or issues with new lawyers' writing. Each participant then reviewed their list with the group, which provoked lively discussion.

In the second stage, participants were shown a letter prepared by a first year associate and asked to comment on it. ${ }^{2}$ In particular, they were asked whether they thought the letter would instill confidence in a client. The letter was a standard reporting letter to a client following a pretrial conference in a wrongful dismissal action. Reporting letters are prepared by lawyers at all levels of experience. Preparing reporting letters is a common activity for the advocacy lawyer; generally they are written after every important stage in a litigation action to provide an updated opinion based on new information and evidence. The reporting letter should advise the client of what occurred at that stage, provide options for action together with a recommendation, and seek

\footnotetext{
${ }^{2}$ The letter was obtained by one of the participants who asked for sample letters from his associates. The letter was revised to remove all client identifiers. We obtained permission to use the letter within the focus groups but not explicit permission to publish its contents.
} 
instructions for future action. The audience may be a single individual or in the case of a corporation, could include general counsel, another corporate officer or employee, or even the board of directors.

Reporting letters are both retrospective and prospective; a letter may be linked back to the lawyer's original opinion to the client on the merits and risks of the action as well as provide predictions about the future. These letters are vital links within an advocacy file, as they are a formal memorialization of a meeting or other event together with analysis and predictions of the future. These letters are shaped not only by the lawyer's legal analysis, but also their understanding of the predilections of particular judges, their own client and possibly the opposing lawyer and client. As one writer notes, "(E)very written communication becomes a part of the litigation and should be crafted with care and with strategic considerations in mind" (West, 2004-5). For these reasons, and because "(L)awyers are letter factories" (Martin, 2000), it is appropriate to analyze letters as evidence of the types of ill-structured problems that require the writer to "solve problems like a professional."

\section{B. DATA SOURCES}

The focus group sessions were transcribed and the transcripts were divided and coded using the following inductively-derived themes: Process, Product, Speculation, Teaching and Learning, and Identity. The Product theme included all statements regarding the final written product. The Process theme included all statements regarding the process of creating the final product, including pre-writing such as outlining as well as revision. The Speculation theme included all statements theorizing about why students and young lawyers write poorly. The Teaching and Learning theme included statements about the participants' own experiences as learners as well as their experiences teaching writing to students and new lawyers. Finally, the Identity theme included any statements by these very experienced practitioners about the connection between their professional identity and their written work.

Because the majority of the participants practiced in large multi-service firms, we can assume that their students and new associates are drawn from a pool of strong students. Canadian law schools, although ranked, do not operate within the "tier" system into which American law schools fall. Arguably, a strong student from any school would likely be equivalent to a strong student from any other Canadian law school. In reviewing the comments on student writing, it is helpful to remember that the participants are discussing high-achieving students.

In order to achieve credibility within this research, negative case analysis was undertaken. To establish dependability, from the outset of the work, all focus groups were audio recorded. Verbatim transcripts for the focus groups were created by a transcriptionist and reviewed/modified by the researchers. The principal investigators and the research assistant coded several parts of the transcripts separately and then met to discuss and agree on the complete coding framework. The final themes were derived from a coding process that started 
with a listing of the units of meaning derived by a line- by- line reading of the transcripts, then moved to an analysis of connections and differences within the units of meaning in order to articulate categories and subcategories, which in turn were combined into the themes articulated above. For a complete listing of the units of meaning, categories and subcategories, and final themes, see Appendix A. Note that there is some overlap in themes - for example, organization was discussed in relation to both final written products and in relation to the overall process used to approach a legal writing task. Organization's relationship to overall understanding was also a discussion topic that fell within the Speculation theme.

While we recognize that focus group research can result in incomplete data, by the end of the third focus group, saturation had been reached in relation to the topics we had addressed with participants. For the purposes of generating information with which to move forward with a more detailed research project, the focus groups provided an efficient, effective method. To illustrate the confirmability of results, when discussing data in Part 3 below, the authors will refer to quoted passages from the focus groups to illustrate how particular themes arise within the data.

\section{PART 3: EMERgent TheMES}

Each theme identified by the focus group participants contained numerous dimensions. Interestingly, while we expected a number of the topics discussed below to emerge, there were also unexpected, yet consistent comments. First, the notion of identity as linked to proficient writing emerged as relevant. Second, some of the speculative comments in relation to young lawyers' writing were not ones that the authors had anticipated. Third, we did not anticipate the strong focus on the importance of revision to expert performance in legal writing.

\section{A. Product: General Discussion}

First, the practitioners were able to describe seven product issues, including: grammar, organization and sequencing, road-mapping, verbosity (both legalese and excessive detail), analysis (including use of authority, attention to facts, identification of counter-arguments, bold conclusions), attention to client problem, and rhetorical issues (audience, purpose and tone).

\section{GRAMMAR}

Grammar issues were noted by several participants in each of the three focus groups; the issues are captured in the following quotes:

- "Appalling grammar"

- "I don't think they have a strong grasp of grammar, basic grammar." 
- "...the basics of writing, making sure you have a sentence and knowing how, the difference between a good sentence and a bad sentence."

\section{ORGANIZATION}

Organization was the second-most frequently noted issue; organization is closely tied to legal analysis and audience. Organization issues were:

- "For me, the number one point was organization. They don't think about the order of sequencing of, of the structure of the thoughts and how that one fits into the other."

- “...it's not sequential enough, one concept doesn't flow to the next."

- "And what I see, especially when reading factums (equivalent to US court briefs), is that you'll often get a series of issues more or less at random."

New lawyers don't grasp the importance of "point-first writing" and leading with the best argument:

- "and just getting your head around point first writing is ...they don't come out of school understanding that, and that is huge."

- "But you've got to go with the best that you've got because you may not get the judge past five pages...lead with your strongest point right away, especially if you're responding."

\section{LEGAL ANALYSIS}

Legal analysis, despite three years at law school, still eludes some students and new lawyers.

The case "dump", without further analysis:

- "so I'll get a memo from a student and there's pages and pages of using cases...you haven't done the work. But you have to figure that out for me and present them to me."

- “...they just say well, here's a case, here's another one, here's twenty cases."

Another form of "case dump" could be described as the "literature dump":

- “...I want a research memo on [without prejudice settlement communications] ...I'll get back [noted Canadian text] whole chapter on without prejudice communications and if that's what I wanted, I've got it on my shelf, I could have read it. So you wind up getting a fifteen or twenty page memo when all you really wanted was them to go out and research whatever they could find...really directed on that narrower point." 
In contrast to the mass of unanalyzed cases, another lawyer noted the problem of bold conclusions unsupported by the cases (also described as the "quantum leap"). These bold conclusions may be contrasted with what some participants noted as the inability to grapple with uncertainty: “...if they are faced with an issue on which there is no clear solution, they can't reason their way through it."

Understanding and use of authority, including understanding of organization of primary and secondary authority (which they learn very early in law school and which presumably would have been reinforced regularly) and the more subtle understanding of norms of legal practice, was viewed as problematic:

- “..there's no rational ordering principles. So maybe they, first they've got a, I'm not sure a Court of Appeals case from 1978 and they just have some Supreme Court of Canada case before or after, and then something from a master."3

- "When I ask them...so you've got this wonderful case that you think's on point. Who was the judge? And they say, oh, I didn't think to look at that."

Insufficient attention to facts was noted, both in terms of the importance of facts to the decision-maker, and how advocates can shape facts to their client's advantage:

- "The characterization of facts is very frequently what's going to convince or not convince."

- "But they do forget, they think if they just lay the facts out that they don't have to keep leaving them in, and that's a real problem, you know, that they'll say, here's what happened, and then they'll start talking about the law and they'll forget that, you know, the facts have to be loaded throughout the entire piece."

- "it's trying to tell a story to somebody, in a persuasive way, hopefully...you've got to persuade the judge you're on the side of the angels... and even if you don't think you're necessarily on the side of the angels, you're trying to pull out the elements as to why this is an important element for the judge to care, why should a judge care."

Analysis is intimately connected to organization:

- 'I'm referring to the intellectual organization of, of the sequencing of thoughts, how are you, how are you going to structure the questions you're asked and the order in which you, you provide either the answers or the analysis. And I'm trying to; sometimes things are backwards, why did you talk about that first when you really need to talk about this first? And, and sometimes when you get them, you missed a step of the analysis by failing to consider what are all the things I have to talk about and what are the order I'm going to talk about them?"

\footnotetext{
${ }^{3}$ In Ontario, a master is a court officer who rules on procedural matters within civil litigation actions.
} 


\section{WORDINESS AND VERBOSITY}

Participants noted two aspects of wordiness and verbosity: the first was the use of legalese and excessive language, while the second was the more subtle issue of excessive detail.

- “..the excessive use of legalese."

- "..keeping a focus on what you're trying to accomplish at the end of the day...too detailed or descriptive, you lose the point, you just get bogged down in verbiage...you're trying to explain all of this stuff which can be irrelevant...what's important, what's not."

- "It takes a long time to learn what you can leave out, what not to say, what's unnecessary."

\section{ATtENTION TO AUDIENCE}

While attention to audience surfaced as an issue in writing for judges, it also was noted as an issue in crafting different types of documents for different readers, such as other lawyers or clients.

- "And they also have to think about who they're really writing to. Because who are, the name at the top of the letter is not always who you're really writing to. We, as lawyers for example, cannot communicate with the other side's client. Many times we'd like to communicate with the other side's client. We can't. But we do know that the letters we write to the lawyer on the other side in many instances are sent over to the client. It's a great opportunity to talk to the other side's client. And if I write the letter for another lawyer, the client won't get it. So I have to write the letter in a way that if he sees it, not only will his lawyer understand what I'm saying, if I'm trying to persuade him on something, but it will be accessible to the client as well."

\section{B. Product: LetTER Discussion}

In contrast to the general discussion, the specific review of the letter focused on document rhetoric (audience and purpose), and the connection between organization and analysis. The participants were universally of the view that the letter did not serve the purpose of providing the client with clear options, including the pros and cons of each, together with a recommendation. As in the general discussion, analysis was tied to organization; the letter was "scattered and disjointed", "talking about things at the end that should be at the beginning", and "not orderly in the options." One participant observed that "they're giving you their process, not shaping their process that will suit you as the reader", thus tying organization to audience needs.

The participants were of the view that the client would probably struggle to understand this letter. First, it was unclear whether the specific client was a lawyer or a human resources director, which might make a difference to their understanding of the law of wrongful dismissal. 
Second, the client was from Quebec, which might affect both their understanding of Ontario law and the procedure for this particular court. Finally, the objective of the letter was to obtain instructions on how to proceed with the matter and this objective would not have been obvious to the client reader.

\section{Process: General Discussion}

The practitioners identified the critical importance of an effective writing process; in particular, revision. Even fairly simple documents required some revision. Newer lawyers did not appreciate the need for revision, nor did they factor in the necessary time (which one participant estimated at $25 \%$ of the writing time).

context:

As a process issue, one participant identified the importance of thinking through the

- "One of the first questions I always ask myself is what is really going on? I mean...what does the bigger picture look like and how do each of these issues fit into the bigger picture?"

Participants identified different approaches to the writing task:

- “...And when I do a memo, I still do an outline. I mean, it's rough and it's flexible and I may do all kinds of things with it, but I just don't get on the computer and...dump my brain out because. The editing of something like that is too much work."

As opposed to:

- “...But I've never written anything that I didn’t just write it first, and then I imposed organization after..."

One participant even identified a "physical" outline: for a complex document, he organized his sources into discrete bundles throughout his office and dictated the document as he moved from one bundle to the next.

\section{Process: LetTer Discussion}

The participants engaged in a lively (and sometimes lengthy) discussion about the process of creating these types of letters, including the virtues of dictating the first draft of a document. The process of document creation is intimately connected to the business of the 
practice of law; the participants speculated that perhaps there was pressure to contain the costs of litigation, which led to a letter having been sent out in its first draft form.

\section{E. SPECULATiON}

Primarily through their general feedback, participants speculated about some of the reasons for weakness in young lawyers' writing skills. These speculations provide valuable topics of inquiry for future research with lawyers who have varying amounts of practice experience.

\section{UNDERSTANDING THE IMPORTANCE OF WRITING}

A number of participants were of the view that an understanding of writing's importance is critical:

- "To do good writing you have to think, you have to start with the assumption that it's intensely important, what you're doing."

Yet there was a widespread sense that younger lawyers did not perceive writing as important:

- “... I get the sense that they [younger lawyers] just don't think it's important."

Note, however, one lawyer's speculation that many aspects of young lawyers' communication difficulties may be driven by their fear of the new advocacy situations they face.

\section{USE OF TECHNOLOGY}

Another area of speculation related to technology's role in the development of strong legal writing. Some participants pointed to the "computer dump" that can occur with electronic source searching, and the negative impact this dump can have on the sorting of relevant sources:

- "It's a function of getting, going from law school and getting free $Q L$ and dashing around and not, I don't know, maybe, I think they're not as thoughtful, I think they're more likely just to sit down and go bup, bup, bup, bup."

- "So, I would much rather have good, recent, high level authority from the Supreme Court of Canada, the House of Lords, a Court of Appeal that I know that our judges will respect, rather than just the piling on of endless lists of cases which are of dubious authority. And guess what, the computer's only making that worse."

Further, the availability of electronic precedents within law firms gave rise to concern:

- "And there is a huge tendency in complicated commercial documents, if you see something new from another transaction or another document, oh, I should add that to my ... precedent. ... [A]nd we bloat and we bloat and we bloat, and we end up with a hundred and twenty page credit agreements that, when you actually get down to them, you have 
approximately six pages that actually do stuff, that define relationships or set out obligations."

In summary, the concern seemed to be that the ready availability of numerous documents leads to less serious thinking about the appropriate use of these sources. Inappropriate source use, in turn, leads to poor content and thus, a poor written product.

\section{READING}

A number of participants voiced opinions about the extent to which younger lawyers read:

- “...[I]t seems to me there is a lack of people reading, you know, as there used to be in the past .... So as an example, I saw, I think it was a discussion about scientific testing, or about the validity of testing. And somebody was writing a comment about has this ... been subject to peer review, and they spelled "peer" p-i-e-r and "review" r-e-v-u-e, which is somebody who's heard about peer review but never read the term."

These decreased reading levels were attributed to poor legal writing for lawyers in early years of practice.

\section{GOOD WRITING AND EXPERIENCE}

Finally, there seemed to be widespread agreement that achieving expertise in legal writing requires time and experience:

- "I think it takes ten years, it's almost magical. Seven years, ten years, but ten years, it's sort of like the light goes off, you don't know a thing until ten years in terms of the practicalities and practising and working and the importance of all of these things."

\section{F. TEACHING AND LEARNING}

The participants discussed both formal and informal learning in the workplace. Formal learning opportunities included workshops provided by the firm as well as those of outside continuing legal education providers, such as the one on judicial writing. Informal learning included use of precedents and feedback on writing as well as continuing relationships with mentors and supervisors. Participants described the importance of one-one learning experiences:

- "And, you know, my writing really improved when I got in with this $\mathrm{QC}^{4}$ guy, he said, you know, seven words in a sentence, that's it, punchy, one noun, one verb, one thought per sentence..."

\footnotetext{
${ }^{4}$ Queen's Counsel - traditionally a Q.C. designation related to the title-holder's faithfulness to the Crown, but more recently, it reflects a recognition of contribution to the legal profession.
} 
- "I was trained in the most inefficient, the most expensive, the most old-fashioned way that it possibly could be done, because I was taught one on one, in a tutorial, which I would have to read my essay aloud to two people, one of whom still remains the brightest lawyer I have ever met in my life anywhere. And to get instant feedback on what you had done was terrifying and deeply sobering. And reading it aloud revealed all the defects in the prose, the fact that you would have to do it week after week meant that you were completely naked and there was, your thought was being judged. And he's still the brightest lawyer I have ever met. He's now the clearest writer in the House of Lords and his judgments are an absolute joy, and I learned a lot."

The two participants from very small firms agreed that, without mentors, they learned through their own mistakes.

The former judge described the importance of feedback from his colleagues at a judicial writing workshop, which he attended at the outset of his judicial career and again about five years into it. In contrast, a senior lawyer described how she found it considerably more difficult to persuade associates to attend a writing workshop than a workshop on some aspect of substantive law.

Across all three focus groups there was some discussion of how the one-one approach had changed since they began practice, with the result that new lawyers appeared to receive less individualized help.

\section{G. IDENTITY}

The study group participants described a strong sense of connection between their writing and their professional identities:

- "You need to be the kind of person who cares that the letter is a mirror of who you are, it's a reflection I guess, it is who you are."

- “... [T]hat is your image, and it's the image you project either to the profession, the world or whatever. And it's either one of crispness or intellectual sloppiness."

\section{DiscuSSION AND CONCLUSIONS}

The themes outlined above allow us to formulate a much more informed set of inquiries for a comprehensive research project aimed at developing a description of increasingly sophisticated writing competencies that develop through the years of practice. Additionally, some of the themes seem to re-enforce aspects of expertise in other domains; it seems likely that while legal writing raises its own domain-specific aspects of expertise- particularly in light of the specific nature of legal analysis - it will also share certain facets of expertise as more generally understood. 
Three caveats must be noted. First, this work was exploratory in nature, and while saturation was reached, the number of research participants was small. As such, conclusions require further validation through additional research. Second, because the survey subjects consisted of advocacy lawyers, a judge, and research lawyers who supported advocacy work, findings cannot be assumed to be transferable to non-advocacy areas of legal writing. Finally, as a result of the manner in which the researchers' initial question was posed - "What is most problematic about novice lawyers' work?" - our subsequent analysis of the data collected requires that we draw inferences about expert performance based on it being the opposite of the problems identified by the research participants.

The focus group results raise questions about the cognitive aspects of expertise in legal writing. For example, discussion of novice writers' difficulty with integration of facts and law could tie in to Weinstein's discussion of how some analysts' work on legal problems occurs primarily in the fact space while others' is focused in a law space. Key to Weinstein's research is the fact that experts are able to integrate the two more effectively than novices. Further research should focus on the ability to illustrate this integration within a written product at various stages of practice.

In relation to Product issues themes identified above, the importance of organization, analysis, and rhetoric - specifically audience and purpose - was consistently raised by focus group participants in both the general feedback and the letter critique. These features seem to tie in to the experts' ability to understand and respond to the "deep structures" of problems. The letter analysis, in particular, was suggestive of lawyers' ability to "name and frame" the problem by placing it within a larger context for analysis. The expert lawyers' ability to comment on the potential implications of this letter being sent to various individuals, and their reference to employment law principles to critique the letter, suggested a ready ability to call on relevant domain knowledge with minimal cognitive effort. Again, both within the general feedback and the letter analysis, participants commented extensively on the need to be able to reach a conclusion after having assessed the risks associated with various options. This ability seems to tie in to the general ability of experts to generate the best solutions to problems.

What we were not able to discern from the feedback in this research was the actual manner in which the experts themselves would go about solving a messy, ill-defined problem. Nor were we able to gauge how the process might differ among lawyers with different levels of experience. Future research using think-aloud protocols and document analysis from lawyers at various stages of their legal careers will augment our understanding of these elements.

Our analysis of the Process theme reveals apparent connections between our expert participants' description of how they achieve good written products and the general literature that describes writing as a continuous, recursive process of planning, writing, and revision. While participants differed to some degree on whether their "first draft" was achieved from a quite structured outline or from a more free flowing articulation of initial analysis, there was uniform agreement about the necessity of using revision to clarify, revise, and generate legal 
arguments. Editing for basic adherence to grammatical norms was also noted to be a key aspect of the revision process. Participants' frustration with novice lawyers' inattention to these basic elements raises questions about the extent to which this problem relates to Williams' theory about novice writing giving rise to cognitive overload and a corresponding (but temporary) regression in basic writing skills. Future research that analyses the differences in a document dealing with the same legal problem, generated by lawyers with different levels of experience, may contribute to additional understanding of the impact of novice transition issues on basic writing abilities. This work will undoubtedly also tie in to the general writing on school to work transitions, which require former students to work more quickly, analyze more complex, multifaceted problems, and manage the anxieties associated with the knowledge that the work being produced is not simply an academic endeavour but part of the ongoing life and progress of a file. In fact, many of the "product" and "process" difficulties described by the research participants are linked to the types of difficulties described in the general school to work transition literature. For example, this novice lawyer appeared unable to connect her writing to its social motive: providing the client with clear options and a recommendation. Her text as written did not function as a strand within the "intricate network"; it appeared to stand alone as a review of an isolated event.

Participant views about the link between good legal writing and professional identity also seem tied to the transition from school, where writing exists to meet academic requirements, to legal practice, where writing forms an integral part of the achievement of client goals and professional success.

Speculation about why novice legal writing differs from expert legal writing reveals tentative ties with the literature on overall expertise in writing, and illustrates clearly the need for individualized interviews with participants in future research studies. First, speculation relating to the amount of general reading done by younger lawyers, and its relationship to their ability to write well, seems to relate to general findings within the research on expert writing that writers who read more write better, and to research findings suggesting that overall amounts of reading have decreased among incoming law students. Interview questions aimed at assessing the amount of reading engaged in by lawyers at different practice stages will need to be related to assessments of written document quality.

Comments about the time-line involved in achieving expertise (approximately 10 years) seemed to be reinforced by participant opinion. However, a more structured assessment of the quality of written documents at different practice stages will provide a more nuanced understanding of how the process of achieving expertise evolves over time.

One of the unexpected areas of speculation within the research that is worthy of further exploration stems from the opinion of a number of participants that young lawyers do not understand the importance of legal writing. If this assumption is true, questions are raised in relation to how to better instill the desired sense of importance in younger lawyers. If the assumption is not true, it may be very useful to determine where the "disconnect" lies between young lawyers' attitudes and senior lawyers' perceptions about those attitudes. Our participants' 
speculations, and their general view of the writing of their new lawyers, illustrate the uphill struggles that new lawyers face in their transition to writing in practice.

These findings have assisted us in developing a framework for the next phase of our research. Participants will consist of lawyers with two years, seven years, twelve years, and eighteen years or greater of practice experience. The research will occur in three stages.

At Stage 1, participants will be asked to write a "closed universe" reporting letter to a client; that is, all background research and facts will be provided. The writer is to use the provided material to report the outcome of a pre-trial procedure on a straightforward contract dispute. We have chosen this subject-matter because the majority of practicing advocates would have some basic understanding, without providing an advantage to the more knowledgeable lawyers with more practice experience. The letter will contain an embedded procedural issue and at least one strategic issue that require the writer to consider multiple potential readers (apart from the client). Participants will be asked to prepare this document within two hours. The documents they produce will be analyzed and compared using the Product themes described earlier in this work.

Stage 2 of the research will occur when participants meet with one member of the research team within 10 days from the first stage. During this meeting they will be asked to revise the document (within a one hour time frame), to engage in a "think-aloud" as they revise, and after having completed the revision, to discuss with the researcher their revision process. The types of questions to be addressed at this stage include: How do you begin the writing process? Do you outline, free-write, other? How do you manage the revision process? Do you budget a certain amount of time for revision? Do you consult others in the firm? [If so, who do you consult and why?] Would you undertake more research between drafts? Do you have an organized approach to revision? The revised documents will be analyzed and compared using the Product themes described below, while the interview and think-aloud protocols will be analyzed and compared using the Process themes discussed earlier in this work.

Following completion of the revised letter, Stage 3 of the research will involve the researcher and participant briefly discussing issues relating to the importance of writing in a professional context, the relationship between reading and writing, and teaching and learning within the firm. These discussions will be analyzed and compared in relation to the Speculation, Identity and Teaching and Learning themes established in this work.

\section{EDUCATIONAL IMPORTANCE}

Our current research, and the additional research that will flow from these initial results, is important for both law school teaching and for the ongoing professional development of junior lawyers. 
At both law school and early practice stages, our overall review of expertise and school to work transition research suggests that it is worth paying attention to how realistic institutional performance expectations are at different stages, in light of writers' exposure to and experience with various contexts within which messy, ill-defined legal problems arise. It is hoped that future research will produce information to assist in this assessment of performance expectations. Participants' discussion of the importance of mentors to their development as writers lends credence to the proposition that mentoring and one-one feedback in law school and through the early years of practice is key to writing success.

Within the law school setting, a few initial observations are offered. First, in response to the literature on expertise that suggests cognitive overload can cause a regression in alreadyacquired skills, it would be useful to consider pre-screening incoming law students for core writing skills. Such an assessment would allow professors to better assess whether problems such as grammar, sentence structure and organization stem mostly from the overload associated with learning substantive aspects of a new (legal) domain, and as such, are more likely to be temporary, or are present prior to the beginning of law school. The latter scenario would allow institutions to recommend remediation strategies to students prior to their commencement of law school.

Next, it seems likely that teaching strategies that emphasize facts, the existence of multiple audiences, and the inter-relatedness of legal and non-legal elements within a legal problem may assist students to develop processes that may foster eventual expert performance. Working through more complex legal writing problems will likely give rise to the need for more individualized feedback in order to foster students' successful completion of assigned projects. This may require that professors issue fewer assignments with more required drafts in order to allow students to work through the intertwined processes of planning, translating thoughts to text, and reviewing. Tackling increasingly sophisticated writing problems probably also requires institutional commitment to ongoing writing instruction throughout law school.

The school to work literature suggests that as students near the end of their law school training, they should be made aware of strategies for learning in the professional work-place. For example, students should be made aware of the depth and breadth of the transition ahead, and efforts should be made to assist them to understand how to learn from others and how to be alert to the situational elements that will surround them within their new roles.

In light of the exploratory nature of this research project, the suggestions above are tentative - they call for further research in order to be confirmed or repudiated. Our hope is that this work will begin to mark a path that has the potential to motivate efforts to develop a realistic approach to law school/law practice education that will foster expertise in legal writing. 


\section{REFERENCES}

Alexander, P. (2003). Can We Get There From Here? Educational Researcher, 32(8), 3-4.

American Bar Association Section of Legal Education and Admissions to the Bar. (1992). Report of the task force on law schools and the profession: Narrowing the gap. Legal education and professional development-An educational continuum (The MacCrate Report). Chicago: American Bar Association.

American Law Institute-American Bar Association Committee on Continuing Professional Education. (1992). A practical guide to achieving excellence in the practice of law: Standards, methods and self-evaluation. Philadelphia: American Law Institute-American Bar Association.

Armstrong, S., \& Terrell, T. (2003). Thinking Like a Writer: A Lawyer's Guide to Effective Writing and Editing (Second ed.). New York: Practising Law Institute.

Bereiter, C., \& Scardamalia, M. (1987). The Psychology of Written Composition. Hillsdale: Lawrence Erlbaum Associates.

Bereiter, C., \& Scardamalia, M. (1993). Surpassing Ourselves: An Inquiry into the Nature and Implications of Expertise. Chicago: Open Court Publishing Company.

Berger, L. (1999). Applying new rhetoric to legal discourse: The ebb and flow of reader and writer, text and context. Journal of Legal Education, 49, 155-184.

Bird, C., \& Kinnaird, W. (2002). Objective Analysis of Advocacy Preferences in prevalent mythologies in one California appellate court. Journal of Appellate Practice and Process, 4(1), 141-165.

Calleros, C. (2006). Legal Method and Writing (5th ed.). New York: Aspen Law and Business.

Carter, M. (1996). What is advanced about advanced composition: A theory of expertise in writing. In G. A. Olson \& J. Drew (Eds.), Landmark Essays on Advanced Composition (pp. 71-80). Mahwah, N.J.: Erlbaum.

Chi, M. T. H., Feltovich, P., \& Glaser, R. (1981). Categorization and representation of physics problems by experts and novices. Cognitive Science, 5, 121-152.

Christensen, L. (2008). The Paradox of Legal Expertise: A Study of Experts and Novices Reading the law. Brigham Young University Education and Law Journal, 2008(1).

Colon-Navarro, F. (1997). Thinking like a lawyer: Expert-novice differences in simulated client interviews. Journal of the Legal Profession, 21, 107-139.

Deegan, D. (1995). Exploring individual differences among novices reading in a specific domain: The case of law. Reading Research Quarterly, 30(2), 154-170.

DeGroot. (1965). Thought and choice in chess. The Hague: Mouton.

Dias, P., Freedman, A., Medway, P., \& Par, A. (1999). Worlds Apart: Acting and Writing in Academic and Workplace Contexts. Mahwah: Lawrence Erlbaum Associates.

Dickerson, D. (2005). Motion potion: Tips for magical memoranda. Practical Litigator, 16(1), 7 11.

Ericsson, K. A. (2005). Recent Advances in Expertise Research: A Commentary on the Contributions to the Special Issue. Applied Cognitive Psychology, 19, 233-241. 
Ericsson, K. A. (Ed.). (1996). The road to excellence: The acquisition of expert performance in the arts and sciences, sports and games. Mahwah, N.J.: Erlbaum.

Ericsson, K. A., \& Kintsch, W. (1995). Longterm Working Memory. Psychological Review, 102, 211-245.

Fitzgerald, J. (1987). Research on Revision in Writing. Review of Educational Research, 57, 481-506.

Flower, L., Hayes, J., Carey, L., Schriver, K., \& Stratman, J. (1986). Detection, Diagnosis, and the Strategies of Revision. College Composition and Communication, 37(1), 16-55.

Flower, L., \& Hayes, J. R. (1977). Problem solving strategies and the writing process. College English, 37, 449.

Freedman, A., \& Adam, C. (1996). Learning to Write Professionally. Journal of Business and Technical Communication, 10(4), 395-427.

Gallacher, I. (2007). "Who are Those Guys": The Results of a Survey Studying the Information Literacy of Incoming Law Students. California Western Law Review, 44, 151-218.

Gardner, H. (1994). Creating Minds: An Anatomy of Creativity Seen through the Lives of Freud, Einstein, Picasso, Stravinsky, Eliot, Graham and Gandhi. New York: Basic Books.

Garner, B. (1991). The Elements of Legal Style. New York: Oxford University Press.

Garner, B. (2001). Legal Writing in Plain English. Chicago: The University of Chicago Press.

Garner, B. (2001-2002). Judges on Briefing: A National Survey. Scribes Journal of Legal Writing, 8, 1-34.

Garth, B., \& Martin, J. (1993). Law schools and the construction of competence. Journal of Legal Education, 43, 469-509.

Goldstein, T., \& Lieberman, J. (1989). The lawyers guide to writing well. Los Angeles: University of California Press.

Hinds, P. J. (1999). The curse of expertise: The effects of expertise and debiasing methods on prediction of novice performance. Journal of Experimental Psychology: Applied, 5, 205221.

Hyatt, W. (2007). A Lawyer's Lament: Law schools and the profession of law. Vanderbilt Law Review, 60, 385-400.

Hyland, K. (2001). Bringing in the reader: Adressee features in academic articles. Written Communication, 18, 549-574.

Kellog, R. J. (1994). The psychology of writing. New York: Oxford University Press.

Kellog, R. J. (2006). Professional Writing Expertise. In K. A. E. e. al (Ed.), The Cambridge Handbook of Expertise and Expert Performance (pp. 389-402). New York: Cambridge University Press.

Klein, G. A. (1993). A recognition primed decision (RPD) model of rapid decision making. In G. A. K. e. al (Ed.), Decision-making in action: Models and methods (pp. 138-147). Norwood: Ablex.

Kosse, S., \& ButleRitchie, D. (2003). How Judges, Practitioners, and Legal Writing Teachers Assess the Writing Skills of New Law Graduates: A Comparative Study. Journal of Legal Education, 53(1), 80-102.

Larkin, J. H. (1980). Models of competence in solving physics problems. Cognitive Science, 4 , 317-345.

Laskin, J. (1999). Forget the Windup and make the pitch. Advocates Society Journal. 
Lee, D. (1996). A few words on choosing words well. Practical Litigator, 7(1), 71-.

LeMaistre, C., \& Paré, A. (2004). Learning in two communities: the challenge for universities and workplaces. Journal of Workplace Learning, 16(1/2), 44-52.

Lesgold, A. (1988). Expertise in a complex skill: diagnosing X-ray pictures. In M. T. H. Chi, R. Glaser \& M. J. Farr (Eds.), The nature of expertise (pp. 311-342). Hillsdale, N.J.: Erlbaum.

Lewis, D. (2004). Common knowledge about appellate briefs: True or False? Journal of Appellate Practice and Process, 6(2), 332-347.

Lundeberg, M. (1987). Metacognitive Aspects of Reading Comprehension: Studying Understanding in Legal Case Analysis. Reading Research Quarterly, 22(4), 407.

Mackenzie, S. (2001). A Mediator's Perspective on Effective Mediation Advocacy. Practical Litigator, 12(3), 17-33.

Martin, J. (2000). How to write letter nonlawyers will read (with sample letters). Practical Lawyer, Jan 2000.

Moulton, C.-A., Regehr, G., Mylopoulos, M., \& MacRae, H. (2007). Slowing down when you should: A new model of expert judgment. Academic Medicine, 82(10 October Supplement), S109-S116.

Neumann, R. (2005). Legal Reasoning and Legal Writing: Structure, Strategy and Style (5th ed.). Boston: Little, Brown and Company.

Neumann, R., Jr. (2000). Donald Schon, the reflective practitioner, and the comparative failures of legal education. Clinical Law Review, 6, 401-426.

Nievelstein, F., vanGog, T., \& Boshuizen, H. (2008). Expertise-related differences in conceptual and ontological knowledge in the legal domain. European Journal of Cognitive Psychology, 20(6), 1043-1064.

Oates, L. (1997). Beating the Odds: Reading Strategies of Law Students Admitted Through Alternative Admissions Programs. Iowa Law Review, 83, 139-160.

Paré, A., \& LeMaistre, C. (2006). Active learning in the workplace: transforming individuals and institutions. Journal of Education and Work, 19(4), 363-381.

Rideout, J. C., \& Ramsfield, J. J. (1994). Legal Writing: A Revised View. Washington Law Review, 69, 35-99.

Robbins, K. (2002-3). Paradigm Lost: Recapturing Classical Rhetoric to Validate Legal Reasoning. Vermont Law Review, 27, 483-564.

Schiess, W. (2002). How to Write for Trial Judges. Practical Litigator, 13(4), 41-45.

Schön, D. (1983). The reflective practitioner: How professionals think in action. New York: Basic Books, Inc.

Schön, D. (1987). Educating the reflective practitioner. San Francisco: Jossey-Bass.

Sherr, A. (2000). The value of experience in legal competence. International Journal of the Legal Profession, 7(2), 95-124.

Smith, M. (2002). Advanced legal writing: Theories and strategies in persuasive writing. New York: Aspen Law and Business.

Stanovich, K. E., \& Cunningham, A. E. (1993). Where does knowledge come from? Specific associations between print exposure and information acquisition. Journal of Educational Psychology, 85, 211-229. 
Stein, J. (2000). How could anyone possibly have comments on my masterpiece? Practical Lawyer, June 2000, 11-22.

Stratman, J. (2002). When Law Students Read Cases: Exploring Relations Between Professional Legal Reasoning Roles and Problem Detection. Discourse Processes, 34(1), 57-90.

Sullivan, W., Colby, A., Wegner, J., Bond, L., \& Shulman, L. (2007). Educating Lawyers. San Francisco: Jossey Bass.

Weinstein, I. (1998). Lawyering in the state of nature: Instinct and automaticity in legal problem solving. Vermont Law Review, 23(1), 1-57.

Wellford, R. (2002). Legal Reasoning, Writing and Persuasive Argument: Lexis-Nexis.

West, R. P. (2004-5). Letters for litigators. Litigation, 31(3), 21-26, 65.

Williams, J. (1991). On the Maturing of Legal Writers: Two Models of Growth and Development. Legal Writing, 1, 1-33.

Winsor, D. (2001). Learning to Do Knowledge Work in Systems of Distributed Cognition. Journal of Business and Technical Communication, 15(1), 5-28.

Wishbow, N. A. (1988). Studies of creativity in poets. Carnegie Mellon, Pittsburg.

Wydick, R. (1998). Plain English for Lawyers (4th ed.). Durham: Carolina Academic Press. 


\section{APPENDIX A - CODING FRAMEWORK}

(Note that repeat entries have been deleted)

\section{Units of Meaning \\ 10 years - light goes off \\ 5-6 years for comfort level \\ Ability to Shift gears}

Ability to teach good writing

Assumption of importance

Assumption of Importance

(lack in younger people)

Assumption of reader's

background knowledge

Attention to facts

Audience

Avoiding procrastination

Better readers are better

writers

Bloat

Bold conclusions

Brain dump

Business of

practice

Clarity

Communication

Completeness

Constant trimming

Context

Cut and paste

Decision making

Dictating

Dictation - iterative process

Different contexts

writing
Categories/Sub-Categories

Speculation

Speculation

Process required for good legal writing

Speculation

Speculation

Speculation

Assumed - final product -

rhetoric

Assumed - final product Product

Assumed - final product - Product

rhetoric

Process required for good Process

legal writing

Speculation

Evidenced - final product

Evidenced - final product

Assumed - final product

Practice realities

Evidenced - final product

Process required for good legal writing

Evidenced - final product Product

Required process for good Process legal writing

Process required for good Process writing

Assumed - final product Product

Evidenced - final product Product

Process used to write Process

Process

of

Understanding of process

required for good writing
Themes

(

Speculation

Speculation

Speculation

Speculation

Product

Product

Product

Practice

Process/Product

Process

Process 


\begin{tabular}{|c|c|c|}
\hline Different types of writing & $\begin{array}{l}\text { Understanding of process } \\
\text { required for good writing }\end{array}$ & Process \\
\hline Edit emails & $\begin{array}{l}\text { Required process for good } \\
\text { legal writing }\end{array}$ & Process \\
\hline $\begin{array}{l}\text { Editing - going through } \\
\text { document again and again }\end{array}$ & Process & Process \\
\hline Effective use of tools & Process used to write & Process \\
\hline Emotion & Process & Process \\
\hline $\begin{array}{l}\text { Expert vs. experienced non- } \\
\text { expert }\end{array}$ & Speculation & Speculation \\
\hline $\begin{array}{l}\text { Failure to take writing } \\
\text { seriously }\end{array}$ & Speculation & Speculation \\
\hline Faulty distinguishing & Evidenced - final product & Product \\
\hline Fear of advocating & Speculation & Speculation \\
\hline Formatting & Process used to write & Process \\
\hline $\begin{array}{l}\text { Free access to QL - lack of } \\
\text { thoughtfulness }\end{array}$ & Speculation & Speculation \\
\hline $\begin{array}{l}\text { Gap }- \text { transition from } \\
\text { school to practice }- \text { is vast }\end{array}$ & Speculation & Speculation \\
\hline Good writing "looks easy" & Speculation & Speculation \\
\hline $\begin{array}{l}\text { Good writing not function } \\
\text { of years }\end{array}$ & Speculation & Speculation \\
\hline Grammar & Evidenced - final product & Product \\
\hline Headings for structure & Process & Process \\
\hline Identity & Identity & Identity \\
\hline Imagination & Speculation & Speculation \\
\hline Imitation & Speculation & Speculation \\
\hline Importance of thinking & $\begin{array}{l}\text { Process required for good } \\
\text { legal writing }\end{array}$ & Process \\
\hline Inattention to statutes & Assumed - final product & Product \\
\hline Intellectual organization & Assumed - final product & Product \\
\hline Intention & $\begin{array}{l}\text { Assumed - final product - } \\
\text { rhetoric }\end{array}$ & Product \\
\hline Lack of reading & Speculation & Speculation \\
\hline $\begin{array}{l}\text { Lack of situational } \\
\text { knowledge }\end{array}$ & $\begin{array}{l}\text { Process required for good } \\
\text { writing }\end{array}$ & Process \\
\hline Lack of thinking & Speculation & Speculation \\
\hline Large scale organization & Process & Process \\
\hline Legal analysis & Assumed - final product & Product \\
\hline Legal Practice & Practice realities & Product \\
\hline Legalaze & Evidenced - final product & Product \\
\hline $\begin{array}{l}\text { Linda Flower - roles of } \\
\text { writers }\end{array}$ & $\begin{array}{l}\text { Process required for good } \\
\text { legal writing }\end{array}$ & Process \\
\hline Maturity and practice & Process & Process \\
\hline
\end{tabular}


Maturity to be torn apart by Speculation colleagues

Mentoring

Misguide impress

Modelling

Multiple audiences

Need time and experience

Need to care

New body of knowledge - Speculation

gap

Not coming to a landing

Nuance

Options

Ordering principles

Organization

Organization
understanding
Outline

Overuse of precedent

Physical outline

Planning

Point first writing

Point form

Potentially different levels of improvement

Practice of Law

Precedents do not replace thinking

Priorities

Problem solving

Professional identity

Proof reading

Proof-read

Speculation

Speculation rhetoric

Speculation

Identity

rhetoric

strategy writing

linked to Speculation

Process

Process

Speculation writing

Identity
Teaching and Learning

Teaching and Learning

Assumed - final product - Product

Evidenced - final product Product

Assumed - final product - Product

Evidenced - final product - Product

Assumed - final product Product

Assumed - final product;

Process required for good

unaltered Assumed - final product

Process used to write

Assumed - final product

Evidenced - final product

Practice Realities

Required understanding of process for good legal

Assumed final product Product

Evidenced - final product Product

Required process for good Process legal writing

Required process for good Process legal writing
Identity

Speculation

Speculation

Teaching and Learning

Speculation

Speculation

Identity

Speculation

Speculation

Process

Process

Product

Product

Process

Speculation

Practice/Speculation

Process

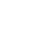




\begin{tabular}{|c|c|c|}
\hline Punchiness & Evidenced - final product & Product \\
\hline Purpose & $\begin{array}{l}\text { Process required for good } \\
\text { legal writing }\end{array}$ & Process \\
\hline Quality of Judgment & Assumed - final product & Product \\
\hline Recommendations & $\begin{array}{l}\text { Evidenced - final product - } \\
\text { strategy }\end{array}$ & Product \\
\hline Relevance & $\begin{array}{l}\text { Process required for good } \\
\text { writing }\end{array}$ & Product \\
\hline $\begin{array}{l}\text { Relevance of reader's } \\
\text { background knowledge }\end{array}$ & $\begin{array}{l}\text { Assumed - final product - } \\
\text { rhetoric }\end{array}$ & Product \\
\hline Research strategy & Assumed - final product & Product \\
\hline $\begin{array}{l}\text { Responsibility } \\
\text { unwillingness to assume }\end{array}$ & $\begin{array}{l}\text { Speculation about } \\
\text { challenges }\end{array}$ & Speculation \\
\hline Risk assessment & $\begin{array}{l}\text { Assumed - final product - } \\
\text { strategy }\end{array}$ & Product \\
\hline $\begin{array}{l}\text { Rules of good writing cut } \\
\text { across disciplines }\end{array}$ & Speculation & Speculation \\
\hline Sequence & Evidenced - final product & Product \\
\hline Sharing product & $\begin{array}{l}\text { Recommended process for } \\
\text { good writing }\end{array}$ & Process \\
\hline Situation knowledge & $\begin{array}{l}\text { Process required for good } \\
\text { product }\end{array}$ & Process \\
\hline $\begin{array}{l}\text { Slowing down the process } \\
\text { of thinking }\end{array}$ & $\begin{array}{l}\text { Process required for good } \\
\text { writing }\end{array}$ & Process \\
\hline Social Context & $\begin{array}{l}\text { Process required for good } \\
\text { writing }\end{array}$ & Process \\
\hline Speculation - generation & Speculation - generational & Speculation \\
\hline $\begin{array}{l}\text { Story telling - naming and } \\
\text { framing }\end{array}$ & $\begin{array}{l}\text { Process required for good } \\
\text { writing }\end{array}$ & Process \\
\hline $\begin{array}{l}\text { Stream of consciousness vs. } \\
\text { outline }\end{array}$ & Process approaches & Process \\
\hline Structure & Evidenced - final product & Product \\
\hline Synthesis & Assumed - final product & Product \\
\hline $\begin{array}{l}\text { Technology deteriorating } \\
\text { performance? }\end{array}$ & Speculation & Speculation \\
\hline $\begin{array}{ll}\text { Think } & \text { through } \\
\text { Counterargument } & \end{array}$ & Product & Product \\
\hline Thinking through advice & $\begin{array}{l}\text { Process required for good } \\
\text { writing }\end{array}$ & Process \\
\hline Throat clearing & Evidenced - final product & Product \\
\hline $\begin{array}{l}\text { Time investment } \\
\text { organizing }\end{array}$ & $\begin{array}{l}\text { Process required for good } \\
\text { legal writing }\end{array}$ & Process \\
\hline Tone & $\begin{array}{l}\text { Assumed - final product - } \\
\text { rhetoric }\end{array}$ & Pro \\
\hline
\end{tabular}




\begin{tabular}{|c|c|c|}
\hline \multirow{3}{*}{$\begin{array}{l}\text { Typing own material } \\
\text { Understanding linked to } \\
\text { clarity } \\
\text { Understanding of problem }\end{array}$} & Process used to write & Process \\
\hline & Speculation & Speculation \\
\hline & $\begin{array}{l}\text { Process required for good } \\
\text { legal writing }\end{array}$ & Process \\
\hline Unsupported conclusions & Evidenced - final product & Product \\
\hline Use of Legal Authority & Evidenced - final product & Product \\
\hline Use of technology & Process & Process \\
\hline $\begin{array}{l}\text { Verbiage among senior } \\
\text { lawyers }\end{array}$ & Evidenced - final product & Product \\
\hline Verbosity & Evidenced - product & Product \\
\hline $\begin{array}{l}\text { Writing as expulsion of } \\
\text { thinking }\end{array}$ & Process & Process \\
\hline Writing Process & Process & Process \\
\hline $\begin{array}{l}\text { Young lawyers don't have } \\
\text { the experience }\end{array}$ & Speculation & Speculation \\
\hline $\begin{array}{lll}\text { Young } & \text { lawyers } & \text { too } \\
\text { imitative } & & \end{array}$ & Speculation & Speculation \\
\hline
\end{tabular}

\section{APPENDIX B - RESEARCH LITERATURE ON NOVICE-EXPERT LAWYERING}

\section{A. READING CASES}

\begin{tabular}{|c|c|c|c|c|c|}
\hline Paper & Question & Method & Participants & Findings & Conclusion/Discussion \\
\hline Lundeberg & Part 1: What & Observed and & law & Experts used 6 & Developed \\
\hline & knowledge & interviewed & professors, & general & analysis guidelines \\
\hline & and & participants as & 2 attorneys & comprehension & help novices: putt \\
\hline & strategies do & they think- & law & strategies: use & case in cont \\
\hline & experts use & aloud while & students & context, & overviewing the ca \\
\hline & $\begin{array}{l}\text { to } \\
\text { understand }\end{array}$ & $\begin{array}{ll}\text { reading } & \text { two } \\
\text { contracts } & \end{array}$ & $\begin{array}{lr}\text { with } & \text { at } \\
\text { least } & \text { a }\end{array}$ & $\begin{array}{l}\text { overview, } \\
\text { rereading }\end{array}$ & $\begin{array}{l}\text { rereading the facts a } \\
\text { important terms, }\end{array}$ \\
\hline & and analyze & cases. & masters & analytically, & synthesizing the \\
\hline & a legal case? & Participants & degree & underlining, & elements. Conducte \\
\hline & $\begin{array}{l}\text { Part II: How } \\
\text { best to teach }\end{array}$ & $\begin{array}{l}\text { were told to } \\
\text { read to prepare }\end{array}$ & & $\begin{array}{l}\text { synthesis, and } \\
\text { evaluation. }\end{array}$ & $\begin{array}{l}\text { further experiment } \\
\text { see which method }\end{array}$ \\
\hline & expert & answer & & Novicees used 5 & delivering \\
\hline & reading & questions in & & strategies & guidelines would \\
\hline & strategies to & class. & & used by & most effective. \\
\hline & $\begin{array}{l}\text { law } \\
\text { students? }\end{array}$ & & & $\begin{array}{l}\text { experts: } \\
\text { expressing }\end{array}$ & $\begin{array}{lr}\text { All law } & \text { stude } \\
\text { benefitted } & \text { fr }\end{array}$ \\
\hline
\end{tabular}


Deegan

(1995)

$\begin{array}{lll}\text { Examines } & \text { Observed } & 20 \text { students } \\ \text { individual } & \text { reading a law who had } \\ \text { reader } & \text { review article; just } \\ \text { differences } & \text { practice with a completed } \\ \text { in a specific } & \text { short text on first year. } \\ \text { domain, and } & \text { how to do a } 10 \text { highest } \\ \text { to determine } & \text { think-aloud. ranked and } \\ \text { if a relation } & \text { Reading task } 10 \text { lowest } \\ \text { exists among } & \text { was to prepare ranked for } \\ \text { strategy use, } & \text { for class; told first year } \\ \text { reading } & \text { to be ready to grade point } \\ \text { outcomes, } & \text { focus on what averages. } \\ \text { and domain } & \text { the text said, } \\ \text { performance } & \text { what it might } \\ \text { as assessed } & \text { mean, and } \\ \text { by grades. } & \text { anything else } \\ & \text { they deemed } \\ & \text { important. } \\ & \text { Then was a } \\ & \text { recitation } \\ & \text { secion, where } \\ \text { interviewer } \\ \text { simulated a } \\ \text { classroom } \\ \text { situation. } \\ \text { Final debriefing on } \\ \text { personal } \\ \text { perceptions } \\ \\ \end{array}$

confusion about legal terms, expressing confusion about English words with legal meanings, contextually defining words, adding incorrect information, and attempting to assign names to the plaintiff and defendant.

Students

primarily used three types of reading strategies:

problematizing, rhetorical, and default.

Problematizing= raising questions about the meaning and structure of the cases. Default $=$ linear progression through the text. Rhetoric $=$ evaluative. Because rhetorical used only about $8 \%$, comparied only problematizing and rhetorical.

Found a difference in cognitive processing, guidelines to varying degrees. Second and third year students not much helped; consider whether different guidelines for different levels of cognitive development might be more appropriate.

Problematizing strategy helpful to these students in this reading situation.

Law schools should look into reading practices of students to make the challenges of this novel discourse public. 
about reading

abilities. where the use of

the

problematizing

strategy

appeared a

better predictor

of first year

performance

than either

LSATs or

undergraduate

GPA

Oates (1997) How do Think-aloud 1 law Professor put students read cases to prepare for class?

\section{while reading} cases;

structured

interview

about

they prepared teaching

for class, LRW.

whether their students

think-aloud admitted

was the same under

or different to special how they admissions

usually read

cases.
Christensen

(2008)

\section{Compares Participants 8}

reading strategies of experts compared to law students.

read a case using think- lawyers aloud method; and purpose of judges, reading was to average 16 prepare for a years, meeting with a range 3-36. client who had a similar case; short interview after the reading.

\section{case}

3
historical and legal context, used analysis, synthesis and evaluation.

4 Needed to read for a specific purpose.

Students

appeared as four different types: expert reader, expert student, misguided student, uncaring student.

Constrast in Support prior research default and on case reading. rhetorical

2 strategies, less in

problematizing. Experts 10 law prior knowledge students, and experience, all within connected to the top $50 \%$ purpose of the after one reading,
To improve odds for special admissions students: explain the differences between legal reading and other types of reading, model reading as an expert, consider diagnostic tests that evaluate students' ability to read cases. 


\begin{tabular}{|c|c|c|c|c|c|}
\hline $\begin{array}{l}\text { Stratman } \\
(2002)\end{array}$ & $\begin{array}{l}\text { Explores } \\
\text { how } \\
\text { different } \\
\text { kinds of real- } \\
\text { world, legal } \\
\text { roles may } \\
\text { affect } \\
\text { students' } \\
\text { ability to } \\
\text { recognize } \\
\text { relevant } \\
\text { legal } \\
\text { reasoning } \\
\text { and meaning } \\
\text { interpretation } \\
\text { problems } \\
\text { arising both } \\
\text { within and } \\
\text { between } \\
\text { cases they } \\
\text { read. } \\
\text { Attempt to } \\
\text { bridge } \\
\text { emerging } \\
\text { cognitive } \\
\text { literature on } \\
\text { lawyering } \\
\text { and reading } \\
\text { studies. }\end{array}$ & $\begin{array}{l}\text { Coded for } \\
\text { three themes: } \\
\text { problematizing } \\
\text { reading } \\
\text { strategies, } \\
\text { default reading } \\
\text { strategies, } \\
\text { rhetorical } \\
\text { reading } \\
\text { strategies. } \\
\text { Asked } \\
\text { students to } \\
\text { read cases in } \\
\text { rhetorical } \\
\text { contexts of } \\
\text { advocatory } \\
\text { role, advisory } \\
\text { role, policy } \\
\text { role, and class } \\
\text { recitation role. } \\
\text { Asked: which } \\
\text { of these roles } \\
\text { would lead } \\
\text { students to } \\
\text { read cases } \\
\text { more are } \\
\text { critically, } \\
\text { which would } \\
\text { lead students } \\
\text { to detect more } \\
\text { problems at } \\
\text { the cross-case } \\
\text { level, and } \\
\text { across all four } \\
\text { roles, } \\
\text { kinds what } \\
\text { problems are } \\
\text { students most } \\
\text { likely } \\
\text { detect? }\end{array}$ & $\begin{array}{l}56 \text { law } \\
\text { students } \\
\text { from } 2 \\
\text { schools; all } \\
\text { in their } \\
\text { second } \\
\text { semester of } \\
\text { law school. } \\
\text { Randomly } \\
\text { assigned. } \\
\text { First given } \\
\text { a think- } \\
\text { aloud task, } \\
\text { then to } \\
\text { write } \\
\text { different } \\
\text { products } \\
\text { based on } \\
\text { their } \\
\text { reading, } \\
\text { with a } 90 \\
\text { minute } \\
\text { time frame. } \\
\text { Think- } \\
\text { alouds } \\
\text { were } \\
\text { scored; }\end{array}$ & $\begin{array}{l}\text { Problem } \\
\text { recognition } \\
\text { rates for the } \\
\text { three real-world } \\
\text { tasks are } \\
\text { consistently } \\
\text { better than the } \\
\text { class recitation } \\
\text { task. On overall } \\
\text { detection } \\
\text { measure, both } \\
\text { advocatory and } \\
\text { policy groups } \\
\text { performed } \\
\text { significantly } \\
\text { better than the } \\
\text { class recitation } \\
\text { group. On the } \\
\text { core item } \\
\text { measure, both } \\
\text { the advocatory } \\
\text { and advisory } \\
\text { groups } \\
\text { performed } \\
\text { significantly } \\
\text { better than the } \\
\text { class recitation } \\
\text { group. } \\
\text { But, problem } \\
\text { detection did } \\
\text { not vary } \\
\text { between the } \\
\text { professional } \\
\text { role and the }\end{array}$ & $\begin{array}{l}\text { Attempt to bring } \\
\text { together studying } \\
\text { problematizing } \\
\text { behavior and problem } \\
\text { recognition behavior. }\end{array}$ \\
\hline
\end{tabular}


academic role. 


\section{B. INTERVIEWING}

\begin{tabular}{|c|c|c|c|c|c|}
\hline Paper & Question & Method & Participants & Findings & Conclusion/Discussion \\
\hline $\begin{array}{l}\text { Sherr } \\
(2000)\end{array}$ & $\begin{array}{l}\text { Examines } \\
\text { the } \\
\text { effectiveness } \\
\text { of the } \\
\text { method of } \\
\text { learning by } \\
\text { experience } \\
\text { alone within } \\
\text { lawyer- } \\
\text { client } \\
\text { interviewing } \\
\text { and notes } \\
\text { where } \\
\text { training } \\
\text { might best } \\
\text { be injected } \\
\text { into the } \\
\text { system }\end{array}$ & $\begin{array}{l}143 \quad \text { live } \\
\text { client } \\
\text { interviews } \\
\text { were } \\
\text { videotaped } \\
\text { and } \\
\text { analyzed- } \\
\text { expert } \\
\text { assessors } \\
\text { looked at } 13 \\
\text { tasks within } \\
\text { an initial } \\
\text { client } \\
\text { interview; } \\
\text { how well } \\
\text { the lawyers } \\
\text { performed } \\
\text { on } 19 \\
\text { techniques } \\
\text { or subskills; } \\
\text { qualities of } \\
\text { 12 } \\
\text { categories } \\
\text { of information; } \\
\text { how well } \\
\text { they thought } \\
\text { the } \\
\text { interview } \\
\text { had gone; } \\
\text { asked } \\
\text { clients how } \\
\text { well they } \\
\text { thought the } \\
\text { interview } \\
\text { had gone. }\end{array}$ & $\begin{array}{l}143 \text { trainees } \\
\text { through to } \\
40-49 \text { ages; } \\
\text { mostly } \\
\text { personal } \\
\text { law with } \\
\text { legal aid } \\
\text { funding. }\end{array}$ & $\begin{array}{l}\text { Lengthy } \\
\text { findings; } \\
\text { quantitative } \\
\text { charts; } \\
\text { minimal } \\
\text { differences } \\
\text { between } \\
\text { experts and } \\
\text { novices; two } \\
\text { significant } \\
\text { differences } \\
\text { were: } \\
\text { opening } \\
\text { question, } \\
\text { and } \\
\text { summarizing } \\
\text { facts and } \\
\text { checking } \\
\text { back with } \\
\text { client. Also } \\
\text { gathered } \\
\text { more } \\
\text { contextual } \\
\text { detail. }\end{array}$ & $\begin{array}{l}\text { Experience seems to } \\
\text { enhance competence } \\
\text { in only a few discrete } \\
\text { areas of performance; } \\
\text { no sequential } \\
\text { progression in ability. } \\
\text { Speculates that this } \\
\text { result may be the } \\
\text { result of experience } \\
\text { without reflection. }\end{array}$ \\
\hline
\end{tabular}




\begin{tabular}{|c|c|c|c|c|c|}
\hline $\begin{array}{l}\text { Colon } \\
\text { Navarro } \\
(1997)\end{array}$ & $\begin{array}{l}\text { Whether } \\
\text { students in } \\
\text { clinical } \\
\text { program } \\
\text { begin to } \\
\text { develop the } \\
\text { "mental file" } \\
\text { of the } \\
\text { experienced } \\
\text { attorney. }\end{array}$ & $\begin{array}{l}\text { Presented } \\
\text { with a } \\
\text { problem and } \\
\text { a } \\
\text { standardized } \\
\text { client, with } \\
50 \text { minutes } \\
\text { for an initial } \\
\text { interview } \\
\text { and } \\
\text { counseling. } \\
\text { Asked to } \\
\text { review } \\
\text { videotape to } \\
\text { elaborate } \\
\text { their } \\
\text { thinking } \\
\text { process and } \\
\text { hypothesis. } \\
\text { Points } \\
\text { awarded for } \\
\text { each "fact" } \\
\text { elicited. }\end{array}$ & $\begin{array}{l}\text { Experts }=4 \\
\text { lawyers } \\
\text { who } \\
\text { practiced } \\
\text { immigration } \\
\text { law, } \\
\text { between 3- } \\
20 \text { years. } \\
\text { Novices = 2 } \\
\text { students } \\
\text { who had } \\
\text { taken both } \\
\text { immigration } \\
\text { course and } \\
\text { clinic. } 1 \\
\text { student who } \\
\text { had taken } \\
\text { only the } \\
\text { immigration } \\
\text { course. }\end{array}$ & $\begin{array}{l}\text { Novices } \\
\text { showed } \\
\text { some } \\
\text { difficulty in } \\
\text { sorting } \\
\text { relevant } \\
\text { from } \\
\text { irrelevant. } \\
\text { Experts } \\
\text { showed high } \\
\text { level of } \\
\text { confidence; } \\
\text { ended with } \\
\text { an outline of } \\
\text { a plan of } \\
\text { action, with } \\
\text { options; } \\
\text { agreed with } \\
\text { each other } \\
\text { on the } \\
\text { hierarchical } \\
\text { ordering of } \\
\text { remedies. } \\
\text { Very fast; } \\
\text { not misled } \\
\text { by red } \\
\text { herrings in } \\
\text { the facts. } \\
\text { Novices got } \\
\text { details } \\
\text { wrong. }\end{array}$ & $\begin{array}{l}\text { Experts had developed } \\
\text { schemas; an } \\
\text { organizational system } \\
\text { with structure and } \\
\text { procedural knowledge. }\end{array}$ \\
\hline
\end{tabular}




\section{Problem Solving}

\begin{tabular}{|c|c|c|c|c|c|}
\hline Paper & Question & Method & Participants & Findings & Conclusion/Discussion \\
\hline $\begin{array}{l}\text { Weinstein } \\
\text { (1998) }\end{array}$ & $\begin{array}{l}\text { What does a } \\
\text { lawyer do } \\
\text { when faced } \\
\text { with a new } \\
\text { legal } \\
\text { situation? }\end{array}$ & $\begin{array}{l}\text { Initial } \\
\text { evaluation } \\
\text { of a Social } \\
\text { Security } \\
\text { Disability } \\
\text { case; tape } \\
\text { recorded as } \\
\text { participants } \\
\text { worked } \\
\text { through the } \\
\text { SSD } \\
\text { problem. }\end{array}$ & $\begin{array}{l}6 \text { law } \\
\text { students: } 3 \\
\text { with } \\
\text { clinical } \\
\text { SSD } \\
\text { experience, } \\
3 \quad \text { with } \\
\text { simulation } \\
\text { SSD lawers } \\
\text { experience. } \\
3 \quad \text { lawyers } \\
\text { experienced } \\
\text { in SSD } \\
\text { work. 1 law } \\
\text { professor } \\
\text { (sub } \\
\text { expert). }\end{array}$ & $\begin{array}{l}\text { Inexperienced: } \\
\text { attended to } \\
\text { information in } \\
\text { the order } \\
\text { presented; } \\
\text { "find } \\
\text { something in } \\
\text { the regs" search } \\
\text { strategy; used } \\
\text { less accurate } \\
\text { and general } \\
\text { formulations; } \\
\text { lack of } \\
\text { attention to } \\
\text { actual language } \\
\text { of the } \\
\text { regulations, } \\
\text { imprecise } \\
\text { analysis and } \\
\text { characterization } \\
\text { of the facts. } \\
\text { Experts paid } \\
\text { attention to bits } \\
\text { of info in a } \\
\text { different } \\
\text { sequence (as if } \\
\text { each had an } \\
\text { individual } \\
\text { template; used } \\
\text { forward } \\
\text { reasoning by } \\
\text { automatic } \\
\text { application of a } \\
\text { rule; required } \\
\text { less } \\
\text { information to } \\
\text { reach } \\
\text { conclusion; } \\
\text { recall and use }\end{array}$ & $\begin{array}{l}\text { Found experts used } \\
\text { two different ways to } \\
\text { approach the problem } \\
\text { - the "law space" and } \\
\text { the "problem space" }\end{array}$ \\
\hline
\end{tabular}




\begin{tabular}{|c|c|c|c|c|c|}
\hline & & & & $\begin{array}{l}\text { very concrete } \\
\text { and particular } \\
\text { information. } \\
\text { Sub expert } \\
\text { reached flawed } \\
\text { conclusion. }\end{array}$ & \\
\hline $\begin{array}{l}\text { Nievelstein } \\
(2008)\end{array}$ & $\begin{array}{l}\text { Investigating } \\
\text { expertise- } \\
\text { related } \\
\text { differences } \\
\text { in } \\
\text { conceptual } \\
\text { knowledge } \\
\text { structures } \\
\text { and } \\
\text { ontology in } \\
\text { law. }\end{array}$ & $\begin{array}{l}\text { Novices = } \\
24 \\
\text { Advanced } \\
\text { students = } \\
24 \\
12 \text { faculty } \\
\text { members, } \\
\text { experts in } \\
\text { civil law, } \\
\text { average 5-9 } \\
\text { years of } \\
\text { professional } \\
\text { experience }\end{array}$ & $\begin{array}{l}\text { Card- } \\
\text { sorting - } 30 \\
\text { different } \\
\text { cards } \\
\text { relating to } \\
\text { torts - } \\
\text { asked to } \\
\text { create } \\
\text { clusters. } \\
\text { Concept } \\
\text { elaboration } \\
\text { task - } \\
\text { provided } \\
\text { with } 5 \\
\text { different } \\
\text { concepts } \\
\text { and asked } \\
\text { to verbalize } \\
\text { everything } \\
\text { they knew } \\
-2 \text { minutes } \\
\text { per } \\
\text { concept. }\end{array}$ & $\begin{array}{l}\text { Novices } \\
\text { showed no } \\
\text { particular } \\
\text { pattern in the } \\
\text { way they } \\
\text { clustered the } \\
\text { concepts; } \\
\text { Experts } \\
\text { mentioned } \\
\text { more central } \\
\text { concepts, more } \\
\text { fields of law, } \\
\text { and more top } \\
\text { concepts. }\end{array}$ & $\begin{array}{l}\text { Knowledge becomes } \\
\text { more hierarchically } \\
\text { structured with } \\
\text { increasing expertise. }\end{array}$ \\
\hline
\end{tabular}

